\title{
Art outcome in combined group of women with premature ovarian failure and menopausal women
}

\section{Rekha Rajendrakumar*, Purnima K. Nadkarni}

\begin{abstract}
Department of Reproductive Medicine, Nadkarni Hospital and Test Tube Baby Centre, Killa Pardi- 395125, Valsad,
\end{abstract} Gujarat, India

Received: 04 March 2016

Revised: 11 April 2016

Accepted: 12 April 2016

\author{
*Correspondence: \\ Dr. Rekha Rajendrakumar, \\ E-mail: dr_rajendrakumar60@yahoo.co.in
}

Copyright: () the author(s), publisher and licensee Medip Academy. This is an open-access article distributed under the terms of the Creative Commons Attribution Non-Commercial License, which permits unrestricted non-commercial use, distribution, and reproduction in any medium, provided the original work is properly cited.

\begin{abstract}
Background: It is to present an overview of the study of the ART cycles in combined group of women with premature ovarian failure (POF) and menopausal women in 1 year period. Purpose of the study was to know the pregnancy outcome in this combined group. Since majority of the patients who entered our tertiary hospital had already received various treatment methods such as gonadotropins, long protocols and ultra-short protocols in previous hospitals with no positive result, we had to take them directly to the ovum donation (OD) or embryo donation (ED).

Methods: A simple study was performed from 1st January, 2015 to 31st December, 2015. Women with POF and menopause were enrolled and complete follow up of them was done from their first visit till stable pregnancy of 14 weeks was achieved. While doing this, we considered various parameters which can affect the ART outcome, for e.g. endometrial evaluation, hysteroscopy findings, proliferative phase preparation, leuteal support, semen analysis etc. The study outcome results included pregnancy rate and miscarriage rate.

Results: In spite of good efforts, ultimately, stable pregnancy rate (beyond 14 weeks gestation) of these women was only $35 \%$ that was almost one third of the total study population that too with the help of OD and ED. Pregnancy rate was actually $42 \%$, out of which $7 \%$ had miscarriage. With all the cost, efforts and time involved, 65\% (2/3rd) of women could not achieve successful pregnancy.

Conclusions: Since the possibility of pregnancy gradually declines after the age of 30 and a steep fall in fertility after the age of 35 , women should be advised not to postpone marriages and should be encouraged to have children earlier.
\end{abstract}

Keywords: Premature ovarian failure, Menopause, Antral follicle count, Infertility, Ovum donation, Embryo donation

\section{INTRODUCTION}

Incidence of premature ovarian failure (POF) is gradually increasing, as present generation women are delaying having families. Other causes noted are autoimmune, genetic, iatrogenic like surgery on the ovary like endometriosis, teratoma or ovarian drilling, hysterectomy, radiotherapy, chemotherapy, viral oophoritis, excessive use of gonadotropins, smoking, occupational exposure to lead and heavy metals etc., Though POF related issues can be usually managed well with hormone replacement therapy (HRT), in an infertility context, POF poses a challenge to the treating physician, as the loss of ovarian function means that the probability of pregnancy with own eggs is greatly reduced. ${ }^{1}$ Most of the women with poor ovarian reserve are deeply upset by the time they realize that they are infertile. Absence of fertility is due to absence of follicles and the inability of remaining follicles to respond to stimulation. Ovulation is erratic, rare and unpredictable and therefore, successful spontaneous pregnancy can occur in only $5-6 \%$ of POF patients. Though recombinant 
follicle stimulating hormone ( $\mathrm{rFSH})$, gonadotropin releasing hormone agonist (GnRH a) flare up protocol, long luteal protocols, GnRH antagonists, use of corticosteroids and growth hormones all have been tried, they have not rendered encouraging response.,

Only treatment possible which can give best result is with the help of donor eggs. Success rate with ovum donation (OD) is only $30 \% .^{4}$ In this study, we have studied the success rate with OD and embryo donation (ED) in patients with POF and menopausal age group.

\section{METHODS}

A simple observational study was conducted for a period of 1 year from $1^{\text {st }}$ January, 2015 to $31^{\text {st }}$ December, 2015. Of the whole outpatient and inpatient population, the patients of POF and menopause were selected for the study. Based on the values of anti mullarian hormone $(\mathrm{AMH})$, follicle stimulating hormone $(\mathrm{FSH})$ and antral follicle count (AFC) of both the ovaries together, cut off values were decided and women who would fit into these criteria were included in the study (Table 1).

This sample size was 46 . Out of this, 3 women were lost to follow up after about 3 months of study. So, the effective sample size dropped to 43.

These 43 women were analysed on the basis of following parameters: Age, effective married life, primary or secondary infertility and menstrual cycle patterns. Effective married life of all women was more than 3 years. Since menopausal women also had the same scenario of infertility problems and same expectations as of POF group, they too were included in the study group.

Few menopausal women had genuine reasons to get into the study like $2^{\text {nd }}$ marriage or death of the previous child. Menstrual pattern in some indicated gradual deterioration of fertility as oligomenorrhoea or hypomenorrhoea whereas in others, it was having regular cycles followed by abrupt cessation of menses. $47 \%$ of them had regular on-going cycles (Table 2).

Under investigations, semen analysis was one of the important parameters. Azoospermic men were encouraged to proceed to percutaneous epididymal sperm aspiration (PESA) or testicular sperm aspiration (TESA) depending on the case. They were informed that if PESA or TESA turns out to be positive, they had bright chance of becoming genetic fathers. Out of the 7 azoospermic men, PESA/TESA was positive in 3. Rest 4 who were negative, were encouraged for ED. Out of the $21 \%$ men who had oligoasthenoteratospermia, $14 \%$ were considered for OD + intra cytoplasmic insemination (ICSI) from husband's sperm as we could retrieve some good sperms. Rest 7\% were taken for ED because of abnormal semen parameters. However, $63 \%$ of men had normal seminogram (Table 3a).
$100 \%$ of the women underwent hysteroscopy as part of basic investigation to rule out intrauterine problems. Those were cleared then and there. Majority of them (81\%) had normal hysteroscopy findings. Pin hole and occluded ostia were not further evaluated since all of them were for embryo transfer. Endometrial scratching was done for all and endometrial sample was taken for tuberculosis polymerase chain reaction (TB PCR) testing in all 43 women. TB PCR was positive in 7 (16\%) of the patients and negative in $84 \%$. Anti tuberculous treatment (ATT) for 6 months was given for TB PCR positive women. But we imbibed them into the study and treatment of infertility, after 1 month of ATT (Table 3b).

Transvaginal sonography (TVS) was also done as part of the investigations. Day 2 TVS was done to count AFC, to visualize uterine architecture, endometrial and cavity abnormalities and also to rule out pelvic pathology (Table $3 \mathrm{c})$.

Laparoscopy was done in only 2 patients as they had abnormality in TVS. One patient had simple ovarian cyst and bilateral hydrosalphinx. Cyst was removed, also bilateral salphingectomy to improve the pregnancy rate. Another patient who underwent diagnostic laparoscopy had $2 \times 2 \mathrm{cms}$ solitary subserous fibroid which was not removed.

Autoimmune profile was done for all. Thyroglobulin antibody was positive in $2(4.65 \%)$ women. Rest of these investigations like antinuclear antibody, antiphospholipid antibody, anticardiolipin antibody and lupus anticoagulant were negative in all 43.

Karyotyping was advised for all the women with the age less than 40 years. Only $26 \%$ of them got karyotyping done and those were all normal.

General debility and psychological state of the couple were improved.

\section{Proliferative phase monitoring and preparation}

After tackling hysteroscopic and laparoscopic abnormalities in early part of the cycle, in the present month, prior to embryo transfer (ET) which is intended to be in next month, the study of endometrial response and growth with the influence of the drugs was studied.

Patient was called for the next visit on the second day of the menses and ovarian quiescence was checked before starting treatment. GnRH analogue 20 units (Triptorelin acetate $0.05 \mathrm{mg}$ ) subcutaneous into the anterior abdominal wall daily for 3 days was given in all menstruating women, either just prior to or on $2^{\text {nd }}, 3^{\text {rd }}$ and $4^{\text {th }}$ day of menstruation to prevent premature secretary changes in the endometrium consequent to the spontaneous rise in luteinizing hormone (LH). 
Proper endometrial preparation was restarted with the following drugs with the intension of ET in this month.

\section{Drugs used for endometrial preparation}

Estrogen (17 beta-estradiol) cutaneous gel 2.5gms.equivalent to $1.5 \mathrm{mgm}$ of estradiol gel.

Tab. Estradiol valerate $2 \mathrm{mg}$ orally twice a day. Estrogen doses were titrated according to endometrial thickness and pattern which was monitored every $3^{\text {rd }}$ day by sonography. Endometrial thickness was measured in the sagital plane.

Tab. Folic acid $5 \mathrm{mg}$, tab. Aspirin $75 \mathrm{mg}$, antioxidants, and arginine sachet all one per day.

Tab. Sildenafil $25 \mathrm{mg}$ for vaginal insertion twice a day.

In patients with history of repeated pregnancy wastage, recurrent implantation failure (RIF) or those with autoimmune investigation positive, prednisolone $8 \mathrm{mg}$ twice a day was added.

Natural micronized progesterone supplementation in the form of $400 \mathrm{mg}$ once daily vaginal tablet was started 48 hours prior to OD + ICSI or ED.

Meanwhile, partners were advised to freeze their semen sample for the fear of inability to give the sample on the day of ICSI whose wives needed OD. Also, they were instructed to give fresh sample on the day of ICSI with prior 2 to 3 days abstinence.

Once the endometrial lining has achieved the thickness of $9 \mathrm{~mm}$ with good triple line, they were considered for ET. In $34(80 \%)$ women, embryos were transferred between days 14 to 16 . In the rest $20 \%$, embryo transfer was done between day 17 and day 19 of the cycle. Some women received ED because either sperms were morphologically abnormal or TESA/PESA were negative (Table 4).

2 fertilized embryos were transferred intrauterine, either on day 3 or day 5 transfers using soft catheters under ultrasound guidance (Table 5).

\section{Leuteal phase support}

Inj. Human Chorionic gonadotropin (HCG) $5000 \mathrm{IU}$ on the next day of ET and then biweekly, totally 5 doses subcutaneous or intramuscular.

Natural micronized progesterone vaginally $400 \mathrm{mgm}$, twice a day.

Tab. Dydrogesterone orally $10 \mathrm{mg}$ twice a day.

Inj. Low molecular weight heparin 20 units subcutaneous once daily.
Estrogen was given 2 tablets thrice a day. Rest of the medicines which were given for the endometrial preparation were continued in the same doses till beta Human Chorionic Gonadotropin ( $\beta \mathrm{HCG}$ ) report.

TVS was not done in the secretary phase.

\section{RESULTS}

Table 1: Inclusion criteria considered for the study.

\begin{tabular}{|ll|}
\hline Parameter & Values \\
\hline AMH & less than $0.5 \mathrm{ngm} / \mathrm{ml}$ \\
\hline FSH & more than $20 \mathrm{mIU} / \mathrm{ml}$ \\
\hline AFC & less than 4 (both the ovaries included) \\
\hline
\end{tabular}

Table 2: History and pattern of the study group patients.

\begin{tabular}{|c|c|c|c|}
\hline & & $\begin{array}{l}\text { Number } \\
\text { of women } \\
\text { (total 43) }\end{array}$ & $\%$ \\
\hline \multirow{2}{*}{ Age } & Less than 40 years & 30 & 70 \\
\hline & More than 40 years & 13 & 30 \\
\hline \multirow{2}{*}{ Infertility } & Primary & 28 & 65 \\
\hline & Secondary & 15 & 35 \\
\hline \multirow{5}{*}{$\begin{array}{l}\text { Menstrual } \\
\text { pattern }\end{array}$} & $\begin{array}{l}\text { Primary } \\
\text { amenorrhoea }\end{array}$ & 0 & 0 \\
\hline & $\begin{array}{l}\text { Regular cycles } \\
\text { with good flow }\end{array}$ & 20 & 47 \\
\hline & $\begin{array}{l}\text { Regular cycles } \\
\text { with } \\
\text { hypomenorrohoea }\end{array}$ & 2 & 10 \\
\hline & $\begin{array}{l}\text { Secondary } \\
\text { amenorrhoea } \\
\text { (more than } 1 \text { year) }\end{array}$ & 5 & 12 \\
\hline & Oligomenorrhoea & 16 & 36 \\
\hline
\end{tabular}

Table 3A: Semen analysis.

\begin{tabular}{|lll|}
\hline & $\begin{array}{l}\text { Number of } \\
\text { men } \\
\text { (total 43) }\end{array}$ & Percentage (\%) \\
\hline Azoospermia & 7 & 16 \\
\hline $\begin{array}{l}\text { PESA/TESA } \\
\text { positive }\end{array}$ & 3 & 7 \\
\hline $\begin{array}{l}\text { PESA/TESA } \\
\text { negative }\end{array}$ & 4 & 9 \\
\hline $\begin{array}{l}\text { Oligo astheno } \\
\text { terato spermia }\end{array}$ & 9 & 21 \\
\hline Normospermia & 27 & 63 \\
\hline
\end{tabular}

14 days after the ET, patient was called for first serum $\beta$ HCG testing. Cut off limit of this sample was taken as 50 $\mathrm{mIU} / \mathrm{ml}$. Second sample was taken one week after the first sample and cut off value considered here was 500 $\mathrm{mIU} / \mathrm{ml}$. 3 days interval was maintained between HCG inj and $\beta$ HCG test. Those who turned out to be $\beta$ HCG negative in the second sample were advised to stop all medication and wait for the spontaneous menstruation. 
They were also counselled to report to the hospital on the second day of next menses. Those, in whom $\beta$ HCG was positive, were instructed to continue with all the medications and to report at 4 weeks from the date of ET for TVS to ascertain presence of intrauterine pregnancy with the presence of gestational sac and fetal heart and also to know whether it was multiple gestation (Table 6).

Table 3B: Hysteroscopic findings.

\begin{tabular}{|lll|}
\hline & $\begin{array}{l}\text { Number of } \\
\text { women } \\
\text { (total 43) }\end{array}$ & Percentage (\%) \\
\hline $\begin{array}{l}\text { Intrauterine } \\
\text { Septum }\end{array}$ & 2 & 5 \\
\hline $\begin{array}{l}\text { Endometrial } \\
\text { polyp }\end{array}$ & 3 & 7 \\
\hline $\begin{array}{l}\text { Intra uterine } \\
\text { adhesions }\end{array}$ & 3 & 7 \\
\hline Normal & 35 & 81 \\
\hline
\end{tabular}

Table 3C: Ultrasonography findings.

\begin{tabular}{|lll|}
\hline & $\begin{array}{l}\text { Number of } \\
\text { women } \\
(\text { total 43) }\end{array}$ & Percentage (\%) \\
\hline Atrophic ovaries & 13 & 30 \\
\hline Intra uterine septum & 1 & 2 \\
\hline Endometrial polyp & 2 & 5 \\
\hline Ovarian cyst & 1 & 2 \\
\hline Subserous fibroid & 1 & 2 \\
\hline $\begin{array}{l}\text { Atrophic uterus } \\
\text { normal }\end{array}$ & 5 & 12 \\
\hline
\end{tabular}

Table 4: Pattern of ET.

\begin{tabular}{|lll|}
\hline Number of & $\begin{array}{l}\text { Numen } \\
\text { women } \\
(\text { total 43) }\end{array}$ & Percentage (\%) \\
\hline OD + ICSI & 36 & 84 \\
\hline ED & 7 & 16 \\
\hline
\end{tabular}

Table 5: Out of the above OD and ED cases.

\begin{tabular}{|lll|}
\hline & $\begin{array}{l}\text { Number of } \\
\text { women } \\
\text { (total 43) }\end{array}$ & Percentage (\%) \\
\hline $\begin{array}{l}\text { Day 3 embryo } \\
\text { transfer }\end{array}$ & 26 & 60 \\
\hline $\begin{array}{l}\text { Day 5 blastocyst } \\
\text { transfer }\end{array}$ & 17 & 40 \\
\hline
\end{tabular}

\section{Pregnancy statistics}

Pregnancy was considered clinically positive when gestational sac was visualized at 4 weeks from the day of ET. If the fetal heart had not appeared by this day, they were called for repeat scan after 1 week to ascertain the same. Women with missed abortion, in whom fetal heart was seen initially and was absent in subsequent scans, were called for repeat scan after 1 week to confirm the diagnosis. Once the diagnosis of missed abortion was made, they were thoroughly counselled and pregnancy was terminated.

Table 6: $\beta$ HCG results.

\begin{tabular}{|lll|}
\hline & $\begin{array}{l}\text { Number of } \\
\text { women } \\
\text { (total 43) }\end{array}$ & Percentage (\%) \\
\hline$\beta$ HCG positive & 18 & 42 \\
\hline$\beta$ HCG negative & 25 & 58 \\
\hline
\end{tabular}

In rest of the 15 women, pregnancy continued uneventfully and was considered stable after 14 weeks of gestational age (Table 7). These 15 pregnancies were ascertained normal by serial clinical, laboratory and USG monitoring. Sildenafil was stopped as soon as $\beta$ HCG was positive.

Table 7: Pregnancy statistics and final outcome.

\begin{tabular}{|llc|}
\hline & \multicolumn{1}{|c|}{$\begin{array}{l}\text { Number of } \\
\text { women } \\
\text { (total 43) }\end{array}$} & Percentage (\%) \\
\hline $\begin{array}{l}\text { Women who had } \\
\text { presence of fetal } \\
\text { heart beat }\end{array}$ & 18 & 41.86 \\
\hline Twin pregnancy & 2 & 4.65 \\
\hline Missed abortion & 3 & 6.97 \\
\hline $\begin{array}{l}\text { Pregnancy } \\
\text { continued beyond } \\
\text { 14 weeks }\end{array}$ & 15 & 34.8 \\
\hline $\begin{array}{l}\text { Pregnant women } \\
\text { aged more than } 40 \\
\text { years( more than } 14 \\
\text { wks gestation) }\end{array}$ & 3 & \\
\hline $\begin{array}{l}\text { Pregnant women } \\
\text { aged less than } 40 \\
\text { years(more than } 14\end{array}$ & 12 & 6.97 \\
wks gestation) & & \\
\hline $\begin{array}{l}\text { Women delivered } \\
\text { during the study } \\
\text { (from the study } \\
\text { group) }\end{array}$ & 9 & 28 \\
\hline $\begin{array}{l}\text { On-going } \\
\text { pregnancy }\end{array}$ & 6 & \\
\hline
\end{tabular}

Estrogens and HCG inj. were stopped at around 14 weeks. Prednisolone was tapered and stopped at 14 weeks. Progestogens, aspirin and low molecular heparin were continued till 34 weeks.

\section{DISCUSSION}

According to Mirkin et al age has no impact on the success, once diagnosis of POF was made. ${ }^{5}$ 
In our small study, $65 \%$ of the women had never experienced pregnancy and $35 \%$ were secondarily infertile. This is to compare with study by Vegetti et al which showed the latter figure at $56 \%$. $^{6}$

ESHRE (December 2015, management of women with POI) suggested that routine ultrasound for AFC is not necessary as the ovarian function may fluctuate in women with POF, follicular activity may be seen subsequently during stimulation, thus not distinguishing POF from other diagnoses. We had considered AFC of all the women. ${ }^{7}$

Original paper by Goldberg et al did not show any follicles in the ovarian biopsy from women with FSH levels beyond $33 \mathrm{mIU} / \mathrm{ml}^{8}{ }^{8}$ The literature search since then resulted in number of papers using FSH cut off value for POF ranging from 20 to $40 \mathrm{mIU} / \mathrm{ml}$ (Noyas et al Del Prato, Borani). ${ }^{9,10}$ La Marca et al said that FSH of 26 $\mathrm{mIU} / \mathrm{ml}$ is the physiological preovulatory peak. ${ }^{11}$

According to Sherman et al and Brockmans et al AFC assessment is better than basal FSH. ${ }^{12,13}$

Satwik R et al concluded that AMH is far better than age and FSH in predicting overall ovarian response. ${ }^{14} \mathrm{La}$ Marca et al found that low AMH was also found in females with good regular cycles and hence women with low AMH alone should not be diagnosed as POF. ${ }^{11}$

It also said that there is no guidance to include laparoscopy routinely including ovarian biopsy. In our study, we performed laparoscopy in only 2 indicated cases.

Some large retrospective studies like Remohi et al and Soares et al have not observed significant difference in outcome according to endometrial thickness, but several others like Borini et al, Teanik et al have found it to be an important prognostic factor for OD. ${ }^{15-18}$ According to Dessolle L, endometrium should be minimum $8 \mathrm{~mm}^{19}$

Also, they administered single injection of $3.75 \mathrm{mgm}$ depot Triptorelin in the withdrawal phase of previous cycle. We had used daily injections of Triptorelin 0.05 mg daily for 3 days. Seadat et al, Simon et al, Check et al, Dilwigi et al have shown that use of GnRH agonist during IVF cycles leads to alteration in hormonal profile of leuteal phase and endometrial histology. ${ }^{20-23}$

10-12\% had karyotype abnormalities in a study conducted by Jino et al and Kolanlari et al. ${ }^{24,25}$ There was no karyotype abnormality in our study.

Most common autoimmune disorder associated with POF is thyroid autoantibody, 14-27\% according to Hock et al. ${ }^{26}$ In our study, $4.65 \%$ women proved positive for the same which was much lower and all other autoimmune parameters were negative. Welt et al proposed that thyroid peroxidase autoantibody should be assayed in all patients of POF. $^{27}$

Two randomized trials by Badway et al and Tartagni et al demonstrated that good estrogen support is necessary for increased pregnancy rate and they had used ethinyl estradiol. $^{28,29}$

In our study, we explained the pros and cons of OD and ED thoroughly to the patients, success rate and that those were the only options left out for them. ${ }^{30}$ We explained the fact that chance of having either spontaneous pregnancy or with the help of various other drugs (explained previously) would be only 5 to $6 \%$, which is merely taking chance. Moreover, one of the etiologies of POF is genetic defect and it will not be transmitted to the offspring when OD or ED is done. ${ }^{31}$ Many studies (Lutjen et al, Sauer et al, Templeton et al, Amerathunga D et al) have made it clear that OD is the most successful treatment for infertile women with POF. ${ }^{32-35}$

Amerathunga D et al suggested transfer of only 2 embryos for optimal implantation rates with least chance of multiple pregnancy. ${ }^{35}$ They showed pregnancy rate of $72 \%$ in an average of 2.5 cycles per patient. Shelling AN in journal of Reproduction and Sterility, November 2010, showed the successful pregnancy rate of $30 \%$ with donor egg or ED. ${ }^{36}$ Our data are in accordance with the latter study and we took about 3 cycles per patient.

Though we achieved a pregnancy rate of $42 \%$, net success rate fell to $35 \%$ after excluding missed abortions which is on par with many other studies. Incidence of miscarriage varied in different studies from $6 \%$ (Galbeya et al) to $25 \%$ (Alagana et al). ${ }^{37,38}$ Incidence of miscarriage was low in our study probably because of good diagnostic and therapeutic hysteroscopy, good quality of metaphase 2 (M2) donor oocytes and embryos and proper proliferative and secretary endometrial support.

Older women who were more than 40 years showed $7 \%$ pregnancy after 14 weeks, whereas women less than 40 gave $28 \%$ stable pregnancy rate. This might have been because of poor endometrial vascularity or poor intrauterine milieu related to age.

\section{CONCLUSION}

Since it is a common, serious, emotionally distressing and irreversible problem which can disintegrate families, it must be dealt on both physical and psychological platforms. Women with POF should be educated about the nature of their disease and current research efforts on fertility aspects.

Though cryopreservation of their own embryos, eggs or ovarian tissue, OD, ED and adoption are the different avenues available, they should be made to understand the importance of early marriage and early child bearing to have their own genetic child. It should not be too late that 
one day the woman comes to realize the shattering truth that she is permanently infertile and can never have a progeny with her own eggs. If the couple seeks medical help at a later stage, the only option presently available to them would be OD, that too, with success not more than 30 to $35 \%$.

\section{Funding: Not required}

Conflict of interest: None declared

Ethical approval: The study was approved by the Institutional Ethics Committee

\section{REFERENCES}

1. Kokcu A. Premature Ovarian Failure from current perspective. J Gyn Endocrinology. 2010;26(8):55562.

2. Akman MA, Erden HF, Tosun SB, Beyazit N. Comparison of agonistic flare up protocol and antagonistic multiple dose protocol in poor responders. J Human Reprod. 2001;16(5):868-70.

3. Keay SD, Mathur RS, Jemkims JM. Assisted conception following poor ovarian response to gonadotrophin stimulation. BJOG. 1997;104(5):5217.

4. Sadeghi MR. New hopes for the treatment of POF. J. Reprod and fertility. 2013;14(1):1-2.

5. Mirkin S, Arslon M, Churikov D. Age as a prognostic factor in POF and human endometrium during the window of implantation. Human Reprod. 2003;20:2104-17.

6. Vegetti W, Alogna F. Study in human reproduction on idiopathic form of POF and early menopause. J. of Human Reprod. 1998;14(11):2731-34.

7. ESHRE premature ovarian insufficiency guidelines development group. Management of women with premature ovarian insufficiency; December 2015. Page 33.

8. Goldberg DJ, Carmel J, Cohen, James Holland. FSH as a factor in diagnosis of POF. New England J Med. 1973;145(8):955-67.

9. Noyas N, Hampton B.S, Benkeley A. Factors useful in predicting the success of oocyte donation, a 3 year retrospective analysis. Fertil Steril. 2001;76(1):92-7.

10. Del Prato, Borani. J. FSH levels in POF.Human Repod. 2006; 24;(12);3082 -89.

11. La Marca A, Sighinolfi G, Radi D. AMH as a predictive marker in ART. Hum Reprod. 2009;16:113-30.

12. Ohlenbusch A, Henneke M, Brockman K, George M, Henfield F. J Comparison of FSH v/s AFC in the diagnosis of POF. Human Mutation, variation, information and disease. 2013;25(4):411.

13. Broakmans FJ, Schiffer GJ, Bancsi LF. Ovarian reserve tests in infertility practice and normal fertile women. Maturitas. 2004;30:205-14.

14. Satwik R, Kochhar M, Gupta SM, Majumdar A. AMH in predicting ovarian response. J Human Reprod Sci. 2012;5(2):206-12.
15. Remohi J, Gartner B, Gallardo E, Yalil. Oocyte donation in women with recurrent pregnancy loss. Hum Reprod. 1997;67:717-23.

16. Soares S, Troncoss C, Bosch E. Age and uterine receptiveness, predictive outcome of oocyte donor cycles. J Clin Endocrinl Metab. 2005;90:4399-04.

17. Borini A, Bafaro G, Violini F. Oocyte donation programme. J Fertil Steril. 2003;63:258-61.

18. Tibiletti M, Testa G, de Lauretis Y, Alogna F, Castoldi E. Prog nostic factors in POF. J. Human Reprod. 2003;13(7):1796-800.

19. Desselle L. Endometrial thickness for IVF success. Human Reprod. 2009;24:3082-9.

20. Saadat. Hormonal profile of leuteal phase with GnRH. Human Reprod. 2004;19:1719-24.

21. Simon C, Bellver J, Vidal C. Similar endometrial development in oocyte donors treated with high or low dose GnRH antagonist compared to GnRH agonist treatment in natural cycles. Human Reprod. 2005;12:3318-27.

22. Check. The future trends of induction of ovulation. Minerva Endocrinol. 1995;35:227-46.

23. Dilwigi AJ, Engman L, Schwidt DW, Beradiva CA, Nelson JC. Lupride acetate microdose protocol v/s leuteal phase Ginerelix protocol for poor responders. J Fertil Steril. 2007;95:2531-33.

24. Jiao X, Qin C, Li J, Qin Y, Gao X, Zhang B, et al. Cytogenetic analysis of 531 Chinese women with POF; Human Reprod. 2012;27(7):2201-7.

25. Kolanlari, Venetis CA, Diedrich K, Tarlatzis BC, Griesinger G. Karyotype study in POF women. J Assist Reprod Genet 2013;25:429-30.

26. Hock, Schoemaker T, Drexhage H.A. POF and autoimmunity. Endocr Rev. 1997;18:107-34.

27. Welt CK. Autoimmune oophoritis in adolescents. Am J Y Y Acod Sci. 2008;68:499-509.

28. Badway S, Sharara FI, Scott RT. Assessment of endometrium in poor responders. Infertility Reprod Med Clinics North Amer. 2007;56:415.

29. Tartagni M, Cicinelli E, De Prgola G, De Salvia M A, Levopa C, Loverro G. Effects of pre treatment with estrogens on ovarian stimulation with gonadotrophins in women with POF. A randomized placebo controlled trial. Fertil Steril. 2007;87:85861.

30. Schiender T, Gee M, Stevens. Poor responders and IVF outcome. Fertil Steril.1997;67(1):93-7.

31. Dixit H, Rao L, Padmalatha V, Raseswari T. Genes governing POF. Elsevier J. 2010;20(6):724-40.

32. Lutjen PJ, Trounson AO, Luton JF, Findley JK, Wood EC, Renou PM. The establishment and maintenance of pregnancy using IVF, ovum donation and embryo donation in IVF. Nature. 1984;307:1745 .

33. Sauer MV. 300 cycles of oocyte donation at University of South California; assessing the effect of age and infertility diagnosis on pregnancy and implantation rates. J Assist Reprod Genet. 1994;11(2):92-6. 
34. Templeton, Sauer MV. Principles of oocyte and embryo donation. Edited by Mark V. Sauer Reprod. Biomed Online. 2006;12(2):153-62.

35. Amerathunga D, Weston G, Osianlis T. IVF with donor eggs in POF and postmenopausal women. $\mathrm{J}$ Assist Reprod Genet. 2009;26(9-10):511- 4.

36. Shilling A. Pregnancy outcome with donor eggs and embryo donation in women with POF. J. of Reproduction and Sterility. 2010;140:633-41.
37. Galbeya TA, Kyrgiore M, Lii TC, Stern C, Nardo L C. Incidence of miscarriage in POF women and role of aspirin. Human Reproduction update. 2006; 13:357-64.

38. Alagana L, Nardo ML, Wakim R. Pregnancy outcome in POF women using donor eggs. Arch. Gyneco Obstet. 2004;298:77-8.

Cite this article as: Rekha R, Nadkarni PK. Art outcome in combined group of women with premature ovarian failure and menopausal women. Int J Reprod Contracept Obstet Gynecol 2016;5:1476-82. 